Article

\title{
Development of Therapeutic Chimeric Uricase by Exon Replacement/Restoration and Site-Directed Mutagenesis
}

\author{
Guangrong Xie ${ }^{\dagger}$, Weizhen Yang ${ }^{\dagger}$, Jing Chen, Miaomiao Li, Nan Jiang, Baixue Zhao, Si Chen, \\ Min Wang * and Jianhua Chen *
}

School of Life Science and Technology, China Pharmaceutical University, No. 24, Tong Jia Xiang, Nanjing 210009, China; 15311030132@stu.cpu.edu.cn (G.X.); 14211030582@stu.cpu.edu.cn (W.Y.); 1020071789@cpu.edu.cn (J.C.); 15211030519@stu.cpu.edu.cn (M.L.); 13211030516@stu.cpu.edu.cn (N.J.); 1244724@stu.cpu.edu.cn (B.Z.); 15211030583@stu.cpu.edu.cn (S.C.)

* Correspondence: minwang@cpu.edu.cn (M.W.); jhchen@cpu.edu.cn (J.C.); Tel.: +86-25-8327-1395 (M.W.); +86-25-8327-1290 (J.C.)

+ These authors contributed equally to this paper.

Academic Editor: Terrence Piva

Received: 30 March 2016; Accepted: 6 May 2016; Published: 20 May 2016

\begin{abstract}
The activity of urate oxidase was lost during hominoid evolution, resulting in high susceptibility to hyperuricemia and gout in humans. In order to develop a more "human-like" uricase for therapeutic use, exon replacement/restoration and site-directed mutagenesis were performed to obtain porcine-human uricase with higher homology to deduced human uricase (dHU) and increased uricolytic activity. In an exon replacement study, substitution of exon 6 in wild porcine uricase (wPU) gene with corresponding exon in $d h u$ totally abolished its activity. Substitutions of exon 5, 3, and $1-2$ led to $85 \%, 60 \%$, and $45 \%$ loss of activity, respectively. However, replacement of exon 4 and 7-8 did not significantly change the enzyme activity. When exon 5, 6, and 3 in $d h u$ were replaced by their counterparts in $w p u$, the resulting chimera $\mathrm{H}_{1-2} \mathrm{P}_{3} \mathrm{H}_{4} \mathrm{P}_{5-6} \mathrm{H}_{7-8}$ was active, but only about $28 \%$ of wPU. Multiple sequence alignment and homology modeling predicted that mutations of E24D and $\mathrm{E} 83 \mathrm{G}$ in $\mathrm{H}_{1-2} \mathrm{P}_{3} \mathrm{H}_{4} \mathrm{P}_{5-6} \mathrm{H}_{7-8}$ were favorable for further increase of its activity. After site-directed mutagenesis, $\mathrm{H}_{1-2} \mathrm{P}_{3} \mathrm{H}_{4} \mathrm{P}_{5-6} \mathrm{H}_{7-8}$ (E24D \& E83G) with increased homology (91.45\%) with dHU and higher activity and catalytic efficiency than the FDA-approved porcine-baboon chimera (PBC) was obtained. It showed optimum activity at $\mathrm{pH} 8.5$ and $35^{\circ} \mathrm{C}$ and was stable in a $\mathrm{pH}$ range of $6.5-11.0$ and temperature range of $20-40{ }^{\circ} \mathrm{C}$.
\end{abstract}

Keywords: uricase; exon replacement/restoration; site-directed mutagenesis

\section{Introduction}

Urate oxidase (uricase; EC 1.7.3.3; Uox) is responsible for the first step of degradation of uric acid into more water-soluble allantoin that can be more readily excreted through the kidneys [1-3]. Uox is found in all three domains of life, but not in all five genera of hominoids (humans, chimpanzees, orangutans, gorillas, and gibbons). As a result, uric acid is the end product of purine metabolism in hominoids, resulting in a 10-fold increase of serum uric acid level compared to non-primate mammals [4,5]. Uric acid production and excretion are normally balanced in humans. Hyperuricemia results from an imbalance between the rates of production and excretion of uric acid [6]. Due to the low solubility $\left(6 \mathrm{mg} / \mathrm{dL}, 20^{\circ} \mathrm{C}\right.$ ) of uric acid, long-term hyperuricemia leads to destructive crystalline urate deposits around joints, in soft tissues, and in some organs, causing a number of disorders, including gout and urate nephropathy associated with tumor lysis syndrome $[7,8]$. Studies have also shown 
that hyperuricemia in humans can increase the risk of cardiovascular diseases, chronic nephropathy, impaired renal function, hypertension, and stroke $[9,10]$.

Due to those severe complications of hyperuricemia, its therapeutic countermeasures have attracted great attention in the medical community. There are currently three major classes of drugs available for reducing uric acid level, namely, uricosuric drugs, uric acid synthesis inhibitors, and recombinant Uox preparations [11,12]. Uricosuric agents promote uric acid excretion, but are ineffective if renal function is impaired. Allopurinol, a strong inhibitor of xanthine oxidase, is the mainstay of therapy in patients with tophaceous gout, renal insufficiency, leukemia, and some inherited disorders. However, some patients are refractory to the therapy and $\sim 2 \%$ of patients receiving allopurinol develop allergic reactions, even severe hypersensitivity syndrome $(\sim 0.4 \%)[13,14]$.

Rasburicase (Fasturtec ${ }^{\circledR}$ ), a recombinant form of Uox from Aspergillus flavus, is the first marketed Uox preparation for the treatment and prophylaxis of acute hyperuricemia resulting from tumor lysis syndrome in children with cancer $[15,16]$. Its outstanding ability to decrease uric acid level and dissolve tophi makes Uox-based therapy a more promising strategy for the treatment of hyperuricemia $[17,18]$. However, the clinical use of rasburicase is limited by its immunogenicity and short half-life [19]. In 2010, pegloticase (Krystexxa), a PEGylated chimeric porcine-baboon Uox, was approved by the USA Food and Drug Administration (FDA) for treatment of chronic gout in adult patients refractory to conventional therapy $[20,21]$. With a higher sequence homology to hypothetic human uricase and PEGylation, the immunogenicity of pegloticase is significantly reduced and half-life prolonged. In addition to the FDA approved porcine-baboon chimera (PBC), investigations on several other chimeric uricases have also been reported, such as canine-human chimeric uricase [22] and porcine-human chimeric uricase [23]. The development of therapeutic uricase for human use is an intractable challenge as activity, stability, and immunoreactivity should all be taken into consideration. As such, the medical community has a strong interest in developing a recombinant "human-like" uricase to treat hyperuricemia and gout [24].

The pseudogene of human uricase was mapped to chromosome 1p22 [25].The eight exons in $d h u$ collectively give a nucleotide sequence of $915 \mathrm{bp}$ and code for 304 amino acids. Although this enzyme is lost in hominoid primates, it is crucial in controlling uric acid levels in other mammals. Porcine uricase, with eight exons and a high homology (87.5\%) to human uricase, was detected to be the most active among mammalian uricases. In this report, exon replacement was performed on wild porcine uricase (wPU) gene with corresponding exon from $d h u$ to investigate the overall detrimental effect of each exon on the enzyme activity. Subsequently, exon restoration was performed on $d h u$ by replacing the three most deleterious exons with corresponding exons from wpu. After further site-directed mutations at amino acid residues 24 and 83, chimeric uricase $\mathrm{H}_{1-2} \mathrm{P}_{3} \mathrm{H}_{4} \mathrm{P}_{5-6} \mathrm{H}_{7-8}$ (E24D \& E83G) with increased activity and higher homology with $\mathrm{dHU}$ was obtained.

\section{Results}

\subsection{Expression and Purification of $\mathrm{dHU}$ and $\mathrm{wPU}$}

Two stop codons in the HU gene were intentionally replaced by the codon of arginine during the chemical synthesis of $d h u$. Both $d h u$ and wpu were confirmed by DNA sequencing and inserted into pET-22b(+) vector. After transformation into E. coli BL 21, positive transformants were screened and cultivated for induced expression of the enzyme. As expected, dHU did not show any catalytic activity in the enzymatic assay (Figure 1). wPU was successfully expressed and purified to homogeneity, as illustrated by the distinct band at $34 \mathrm{kDa}$ on SDS-PAGE in Figure 2. 


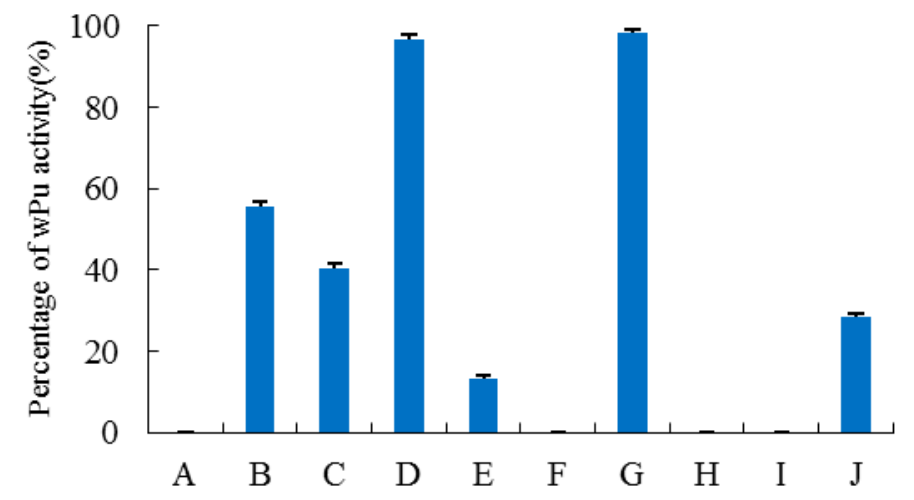

Figure 1. Enzymatic activity of porcine-human chimeras generated during exon replacement and exon restoration study. The enzymatic activity is expressed as a percentage of the activity observed for wPU. ( $n=5$, error bars represent standard deviation). (A) dHU; (B) $\mathrm{H}_{1-2} \mathrm{P}_{3-8}$; (C) $\mathrm{P}_{1-2} \mathrm{H}_{3} \mathrm{P}_{4-8}$; (D) $\mathrm{P}_{1-3} \mathrm{H}_{4} \mathrm{P}_{5-8}$; (E) $\mathrm{P}_{1-4} \mathrm{H}_{5} \mathrm{P}_{6-8} ;$ (F) $\mathrm{P}_{1-5} \mathrm{H}_{6} \mathrm{P}_{7-8}$; (G) $\mathrm{P}_{1-6} \mathrm{H}_{7-8} ;$ (H) $\mathrm{H}_{1-5} \mathrm{P}_{6} \mathrm{H}_{7-8}$; (I) $\mathrm{H}_{1-4} \mathrm{P}_{5-6} \mathrm{H}_{7-8}$; (J) $\mathrm{H}_{1-2} \mathrm{P}_{3} \mathrm{H}_{4} \mathrm{P}_{5-6} \mathrm{H}_{7-8}$.

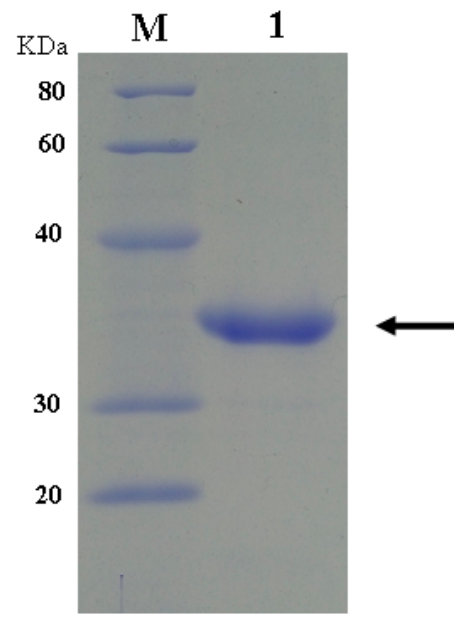

Figure 2. Homogeneity of purified wPU by SDS-PAGE analysis. Lane 1: purified wPU; lane M: molecular weight markers.

\subsection{Construction, Purification, and Enzymatic Assay of Porcine-Human Uricases}

Since exon 1 of human uricase is only $30 \mathrm{bp}$, exons 1 and 2 were investigated collectively, as were exons 7 and 8. By SOE-PCR (splicing by overlap extension-PCR), Exons 1-2, 3, 4, 5, 6, 7-8 of wpu were respectively replaced by the corresponding exon in $d h u$. All these chimeric uricases were successfully constructed, expressed, and purified. As shown in Figure 1, replacement of different exons led to varying deleterious effects on enzyme activity. Substitutions of exon 4 and exons 7-8 in wpu did not cause significant change in activity. However, when exon 6 of $w p u$ was replaced by the corresponding exon of $d h u$, chimera $\mathrm{P}_{1-5} \mathrm{H}_{6} \mathrm{P}_{7-8}$ totally lost its activity. Replacement of exon 5 in wpu by the corresponding exon in $d h u$ significantly deteriorated the activity, with only $14.3 \%$ activity retained in chimera $\mathrm{P}_{1-4} \mathrm{H}_{5} \mathrm{P}_{6-8}$. Replacement of exons 1-2 and exon 3 in wPU was also destructive, but the activity of $\mathrm{H}_{1-2} \mathrm{P}_{3-8}$ and $\mathrm{P}_{1-2} \mathrm{H}_{3} \mathrm{P}_{4-8}$ were moderate compared with that of $\mathrm{wPU}$.

For the resurrection of $\mathrm{dHU}$, a series of exon restoration experiments were carried out. Exons from $w p u$ were substituted for the corresponding exons in $d h u$ one after another, from the most detrimental exon to the least destructive ones. To our surprise, both $\mathrm{H}_{1-5} \mathrm{P}_{6} \mathrm{H}_{7-8}$ and $\mathrm{H}_{1-4} \mathrm{P}_{5-6} \mathrm{H}_{7-8}$ did not show any activity. When the two most detrimental exons in $d h u$ were replaced by functional exons from wpu, it was still not enough to recover any activity. Only when exon 3 was further replaced did chimera $\mathrm{H}_{1-2} \mathrm{P}_{3} \mathrm{H}_{4} \mathrm{P}_{5-6} \mathrm{H}_{7-8}$ begin to show certain activity, about $28 \%$ of wPU. 
In the assay of kinetic parameters, the most satisfactory results were observed with $\mathrm{H}_{1-2} \mathrm{P}_{3} \mathrm{H}_{4} \mathrm{P}_{5-6} \mathrm{H}_{7-8}$ (E24D \& E83G). As shown in Table 1, $\mathrm{H}_{1-2} \mathrm{P}_{3} \mathrm{H}_{4} \mathrm{P}_{5-6} \mathrm{H}_{7-8}$ (E24D \& E83G) displayed a smaller $K_{m}$ than $\mathrm{dHU},{ }_{\mathrm{wPU}}$, and $\mathrm{PBC}$, indicating enhanced activity, which is more desirable to clinical application. It also showed the highest catalytic efficiency, as indicated by $k_{c a t} / K_{m}$. Based on amino acid sequence alignment, $\mathrm{H}_{1-2} \mathrm{P}_{3} \mathrm{H}_{4} \mathrm{P}_{5-6} \mathrm{H}_{7-8}$ (E24D \& E83G) is 91.45\% homologous to dHU.

Table 1. Kinetic parameters for Uox of dHU, wPU, $\mathrm{H}_{1-2} \mathrm{P}_{3} \mathrm{H}_{4} \mathrm{P}_{5-6} \mathrm{H}_{7-8}$ (E24D \& E83G), and PBC.

\begin{tabular}{cccccc}
\hline Uricase & $\boldsymbol{K}_{\boldsymbol{m}} \mathbf{( M m )}$ & $\boldsymbol{k}_{\text {cat }} /(\mathbf{s})$ & $\boldsymbol{k}_{\text {cat }} / \boldsymbol{K}_{\boldsymbol{m}} /(\mathbf{s} / \mu \mathbf{M})$ & Specific Activity & Homology with dHU (\%) \\
\hline $\mathrm{dHU}$ & $\mathrm{ND}$ & $\mathrm{ND}$ & $\mathrm{ND}$ & $\mathrm{ND}$ & 100 \\
\hline $\mathrm{wPU}$ & $10.12 \pm 0.10$ & $23.54 \pm 0.03$ & 2.33 & $4.32 \pm 0.07$ & 87.5 \\
\hline $\begin{array}{c}\mathrm{H}_{1-2} \mathrm{P}_{3} \mathrm{H}_{4} \mathrm{P}_{5-6} \mathrm{H}_{7-8} \\
(\mathrm{E} 24 \mathrm{D} \& \mathrm{E} 3 \mathrm{G})\end{array}$ & $5.37 \pm 0.09$ & $30.95 \pm 0.01$ & 5.76 & $6.03 \pm 0.06$ & 91.45 \\
\hline $\mathrm{PBC}$ & $7.51 \pm 0.04$ & $27.24 \pm 0.03$ & 3.62 & $5.19 \pm 0.08$ & 89.5 \\
\hline
\end{tabular}

Values are means \pm standard deviation of five replicates; ND, not determined.

\subsection{Multiple Sequence Alignment and 3D Structure Modeling}

In Figure 3, the amino acid sequence of $\mathrm{H}_{1-2} \mathrm{P}_{3} \mathrm{H}_{4} \mathrm{P}_{5-6} \mathrm{H}_{7-8}$ was aligned with the amino acid sequences of $\mathrm{dHU}$, three mammal uricases (porcine, baboon, and canine), and three chimeric uricases (porcine-human, porcine-baboon, and canine-human). Amino acid residues of inconsistence across these sequences were highlighted. All these inconsistent residues were shared by both functional sequences and nonfunctional sequence except amino acid residues 24 and 83 . D24 and G83 are found in all the functional uricases in the alignment, while the two positions in $\mathrm{dHU}$ and $\mathrm{H}_{1-2} \mathrm{P}_{3} \mathrm{H}_{4} \mathrm{P}_{5-6} \mathrm{H}_{7-8}$ are E24 and E83, respectively. Therefore, we speculated that the two amino acid residues were the reasons for the low activity observed for $\mathrm{H}_{1-2} \mathrm{P}_{3} \mathrm{H}_{4} \mathrm{P}_{5-6} \mathrm{H}_{7-8}$.

To predict if site-directed mutations at positions 24 and 83 will be favorable for the further restoration of enzyme activity, 3D structures of $\mathrm{H}_{1-2} \mathrm{P}_{3} \mathrm{H}_{4} \mathrm{P}_{5-6} \mathrm{H}_{7-8}$ before and after amino acid replacement at the two positions were constructed and analyzed by homology modeling.

Based on the elucidated crystal structures of uricase from microorganisms and mammals, active uricase folds into a homotetramer (dimer of dimers) in which the monomers are associated by non-covalent binding. Any factor causing the disassociation of the tetramer will lead to exposure of inner hydrophobic amino acid residues and final precipitation of the enzyme, significantly deteriorating the enzymatic activity. As shown in Figure 4, amino acid residue 24 is at the interface of two uricase monomers that form a dimer of the homotetramer. Aspartic acid forms hydrogen bonds with both Lys291 and Tyr289 from the neighboring monomer, which is favorable to the stability of the dimer. However, glutamic acid forms hydrogen bond with neighboring Val47 in the same monomer, consequently moving away from Lys291 and Tyr289 in the adjacent monomer. The increased distance is unfavorable to the association of the two monomers and thus the stability of the dimer.

Each monomer of uricase contains four long $\alpha$-helixes (H1-4) and two short ones (h1-2). As shown in Figure 5, amino acid 83 is located at the connection of two adjacent antiparallel $\alpha$-helixes H1 and H2. Compared with glycine, glutamic acid increases the steric hindrance at the cornering between the two $\alpha$-helixes due to its much larger side chain, greatly affecting the spatial orientation of the two helixes. At the distal end of H2, two amino acid residues (Thr68 and Asp69) forming part of the uric acid-binding site are located. Glu83 is very likely to influence the accurate positioning of Thr68 and Asp69 and consequently the enzyme activity. 


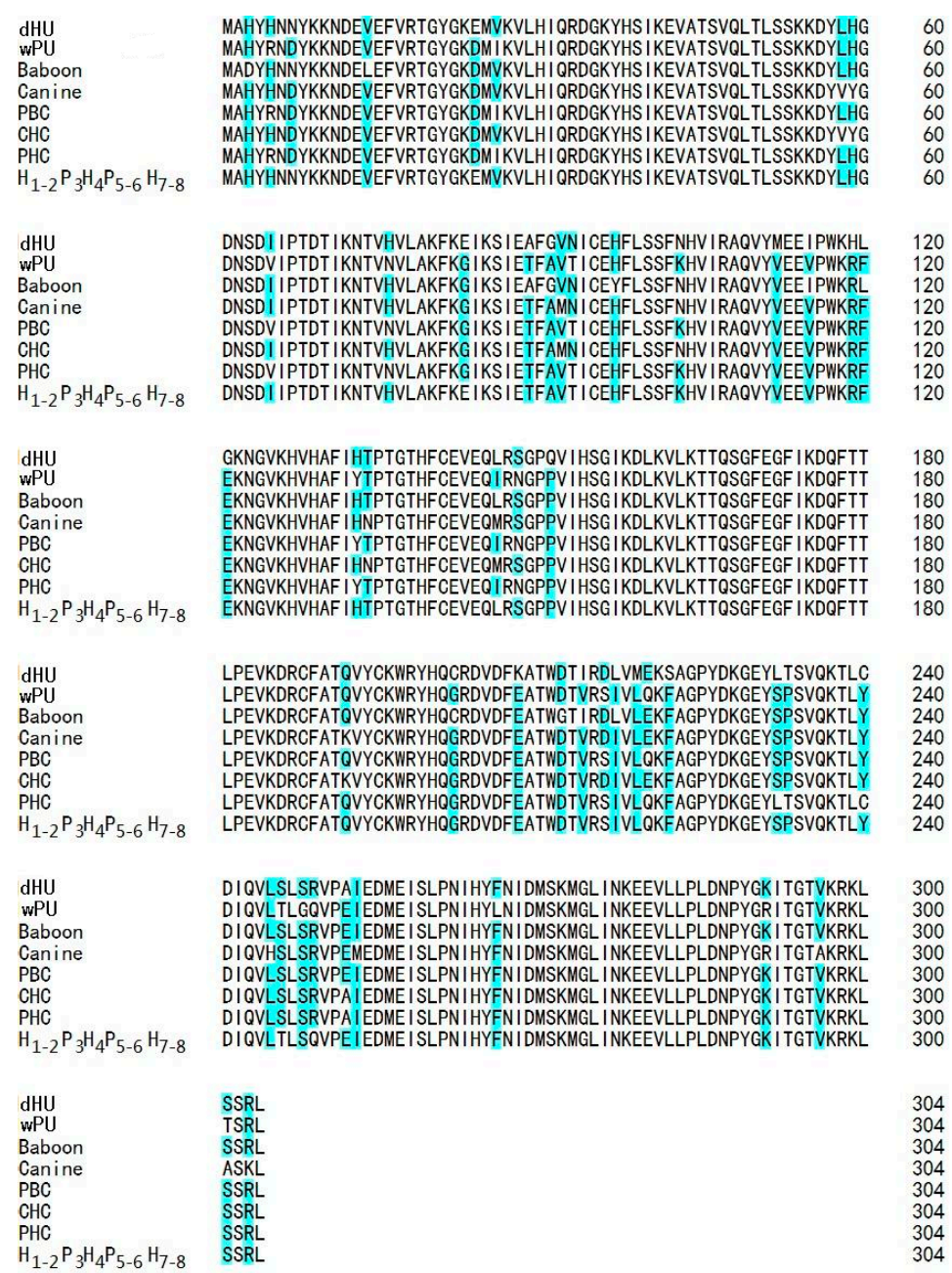

Figure 3. Alignment of deduced protein sequences of $\mathrm{H}_{1-2} \mathrm{P}_{3} \mathrm{H}_{4} \mathrm{P}_{5-6} \mathrm{H}_{7-8}$ with nonfunctional $\mathrm{dHU}$ and six functional Uox. Protein sequences are given as standard single-letter designations. DNA sequences of dHU (AB074326.2 with correction of the two stop codons), baboon uricase (BAB91554.1), canine uricase (NP_001069116.1), and porcine uricase (NP_999435.1) are retrieved from GenBank. DNA sequences of pthe orcine-baboon chimera (PBC), porcine-human chimera (PHC), and canine-human chimera ( $\mathrm{CHC}$ ) were obtained from related patents. Inconsistent amino acid residues are highlighted with light blue.

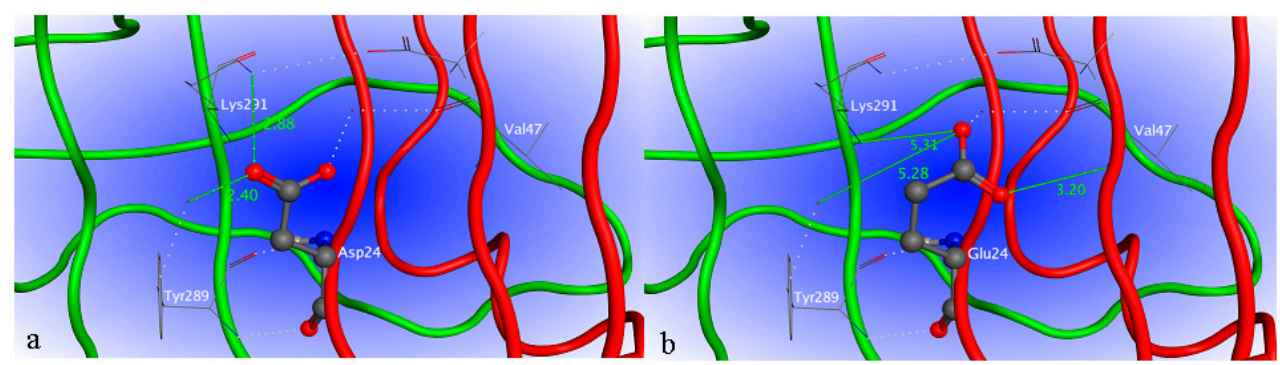

Figure 4. Part of the tertiary structure of $\mathrm{H}_{1-2} \mathrm{P}_{3} \mathrm{H}_{4} \mathrm{P}_{5-6} \mathrm{H}_{7-8}$ before and after amino acid replacement at position 24, constructed using MOE (Molecular Operating Environment). Amino acid residue 24 is shown as a ball and stick structure. The carbon atoms are shown in gray ball, the oxygen atoms are shown in red ball, the nitrogen atoms are in dark blue ball. Backbones of two neighboring monomers are shown in red and green. (a) 3D structure with amino acid residue D24; (b) 3D structure with amino acid residue E24. 


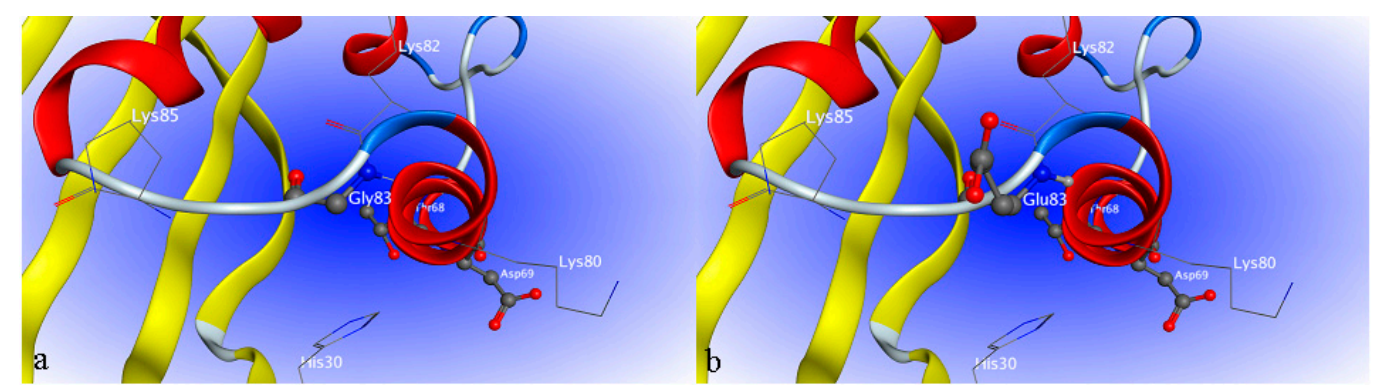

Figure 5. Part of the tertiary structure of $\mathrm{H}_{1-2} \mathrm{P}_{3} \mathrm{H}_{4} \mathrm{P}_{5-6} \mathrm{H}_{7-8}$ before and after amino acid replacement at position 83, constructed using MOE. Amino acid residue 83 is shown as a ball and stick structure. The $\alpha$-helix is shown in red; the $\beta$-sheet is shown in yellow. (a) 3D structure with amino acid residue G83; (b) 3D structure with amino acid residue E83.

\subsection{Site-Directed Mutagenesis}

Based on the predictions by homology modeling, two pairs of primers were designed for the site-directed mutagenesis at positions 24 and 83 in $\mathrm{H}_{1-2} \mathrm{P}_{3} \mathrm{H}_{4} \mathrm{P}_{5-6} \mathrm{H}_{7-8}$ by SOE-PCR. After construction, transformation, and screening by ampicillin, mutants $\mathrm{H}_{1-2} \mathrm{P}_{3} \mathrm{H}_{4} \mathrm{P}_{5-6} \mathrm{H}_{7-8}$ (E24D) and $\mathrm{H}_{1-2} \mathrm{P}_{3} \mathrm{H}_{4} \mathrm{P}_{5-6} \mathrm{H}_{7-8}$ (E24D \& E83G) were obtained and purified for activity assay. As shown in Figure 6, when mutation E24D was performed on chimera $\mathrm{H}_{1-2} \mathrm{P}_{3} \mathrm{H}_{4} \mathrm{P}_{5-6} \mathrm{H}_{7-8}$, there was an obvious increase in the activity, although to a level that is still not comparable to that of wPU and PBC. When both mutations E24D and E83G were implemented, the resulting mutant showed significantly increased activity ( $141 \%$ of $\mathrm{wPU})$, which was even higher than that of PBC. During the process of exon restoration and site-directed mutation, the homology of the resulting chimera with $\mathrm{dHU}$ was gradually decreased. However, $\mathrm{H}_{1-2} \mathrm{P}_{3} \mathrm{H}_{4} \mathrm{P}_{5-6} \mathrm{H}_{7-8}$ (E24D \& E83G) was still $91.45 \%$ homologous to dHU, which was higher than both wPU $(87.5 \%)$ and PBC (89.4\%).

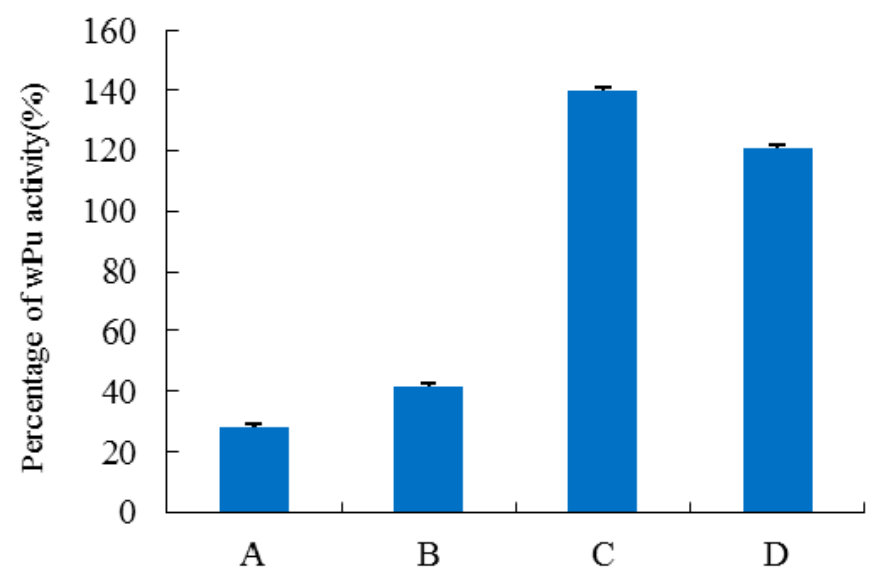

Figure 6. Specific activity determined for mutants obtained by site-directed mutagenesis. Values are expressed as a percentage of the specific activity observed for wPU. $(n=5$, error bars represent standard deviation). (A) $\mathrm{H}_{1-2} \mathrm{P}_{3} \mathrm{H}_{4} \mathrm{P}_{5-6} \mathrm{H}_{7-8}$; (B) $\mathrm{H}_{1-2} \mathrm{P}_{3} \mathrm{H}_{4} \mathrm{P}_{5-6} \mathrm{H}_{7-8}$ (E24D); (C) $\mathrm{H}_{1-2} \mathrm{P}_{3} \mathrm{H}_{4} \mathrm{P}_{5-6} \mathrm{H}_{7-8}$ (E24D \& E83G); (D) PBC.

\subsection{Interaction between $\mathrm{H}_{1-2} \mathrm{P}_{3} \mathrm{H}_{4} P_{5-6} \mathrm{H}_{7-8}$ (E24D \& E83G) and Uric Acid}

The interactions between uric acid and $\mathrm{H}_{1-2} \mathrm{P}_{3} \mathrm{H}_{4} \mathrm{P}_{5-6} \mathrm{H}_{7-8}$ (E24D \& E83G) were simulated in silico (Figure 6). Two types of intermolecular interactions, H-bonding and $\pi-\pi$ interaction, were observed between uric acid and the binding pocket of uricase $\mathrm{H}_{1-2} \mathrm{P}_{3} \mathrm{H}_{4} \mathrm{P}_{5-6} \mathrm{H}_{7-8}$ (E24D \& E83G). As shown in Figure 7, the H-bonding is formed between T68, D69, R187, V235, and uric acid, while the $\pi-\pi$ interaction is formed between F170 and uric acid. This interaction is very similar to that observed 
for uric acid and uricase of microbial origin, such as Aspergillus flavus uricases (PID ID: 4PR8) and Arthrobacter globiformis uricase (PID ID: 2YZB). The purine ring of uric acid is tightly held to one monomer of uricase through molecular tweezers built by the side chains of a conserved Arg and a conserved Gln, and is stacked on a conserved Phe. However, more involvement of V235 was observed in the case of our mutant enzyme.

A

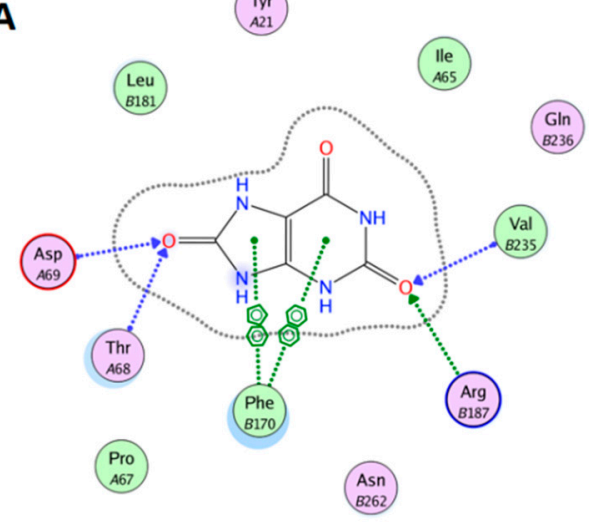

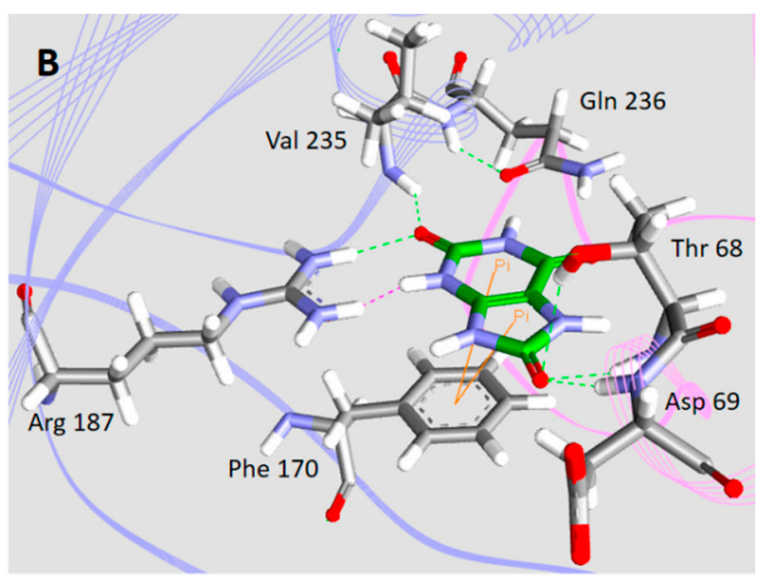

Figure 7. Structure modeling of uric acid to $\mathrm{H}_{1-2} \mathrm{P}_{3} \mathrm{H}_{4} \mathrm{P}_{5-6} \mathrm{H}_{7-8}$ (E24D \& E83G) is illustrated in both 2D and $3 \mathrm{D}$ view $(\mathbf{A}, \mathbf{B})$. In $2 \mathrm{D}$ views, intermolecular interactions between the receptor and the ligand are illustrated, with (A) and (B) indicating amino acid residues from different subunits. In 3D views, both uric acid and amino acid residues involving in the binding are shown as stick structures. Subunit (A) is shown in pink whereas unit (B) is shown in blue. The carbon atoms in uric acid are shown in green, the carbon atoms in amino acid residues are shown in gray, the oxygen atoms are shown in red, and the nitrogen atoms are shown in blue.

\subsection{Characterization of $\mathrm{H}_{1-2} \mathrm{P}_{3} \mathrm{H}_{4} \mathrm{P}_{5-6} \mathrm{H}_{7-8}$ (E24D \& E83G)}

The temperature-activity and -stability profiles of purified $\mathrm{H}_{1-2} \mathrm{P}_{3} \mathrm{H}_{4} \mathrm{P}_{5-6} \mathrm{H}_{7-8}$ (E24D \& E83G) are illustrated in Figure 8a,b in comparison with wPU and PBC. $\mathrm{H}_{1-2} \mathrm{P}_{3} \mathrm{H}_{4} \mathrm{P}_{5-6} \mathrm{H}_{7-8}$ (E24D \& E83G) was optimally active at $35{ }^{\circ} \mathrm{C}$ vs. wPU and $\mathrm{PBC}$ at $40{ }^{\circ} \mathrm{C}$. After $30 \mathrm{~min}$ pre-incubation at different temperatures, all three enzymes showed similar temperature stability profiles. Activity was retained well above $80 \%$ in the range from $25-45^{\circ} \mathrm{C}$ and substantially lost after pre-incubation at $45-60{ }^{\circ} \mathrm{C}$. However, in the range of $25-35^{\circ} \mathrm{C}$, which is also the temperature range at which clinical application occurs, $\mathrm{H}_{1-2} \mathrm{P}_{3} \mathrm{H}_{4} \mathrm{P}_{5-6} \mathrm{H}_{7-8}$ (E24D \& E83G) was slightly more stable than wPU and PBC.
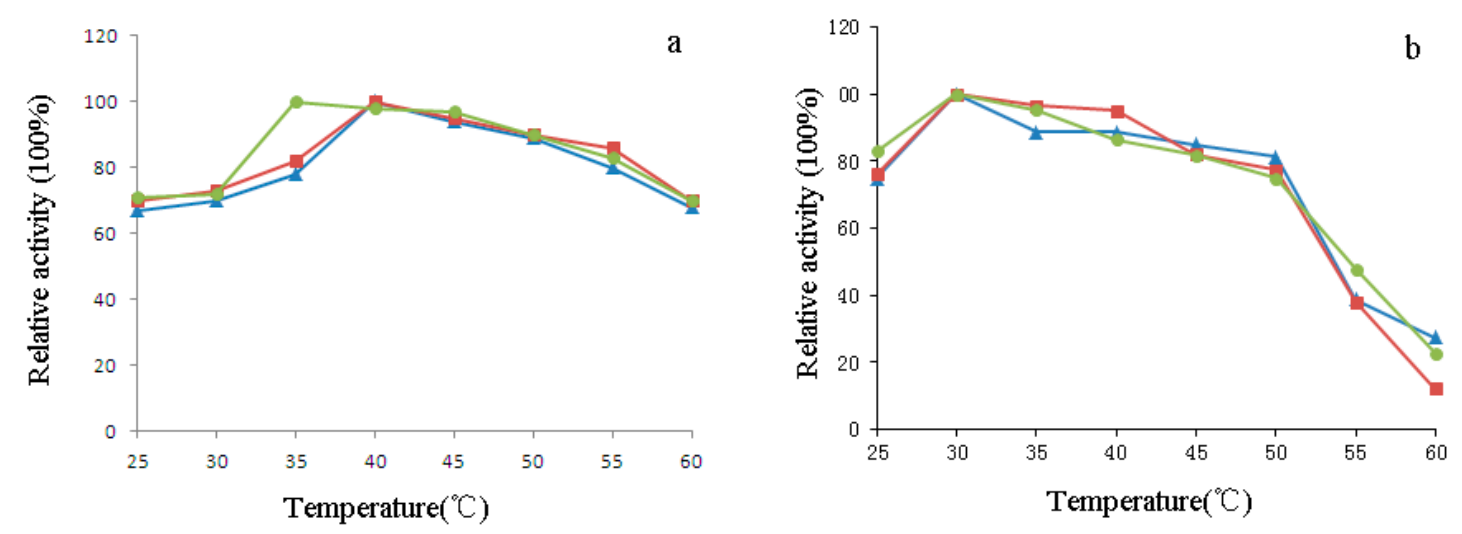

Figure 8. Effect of temperature on uricolytic activity (a) and stability (b) of wPU ( $\mathbf{\Delta}), \operatorname{PBC}(\boldsymbol{\square})$, and $\mathrm{H}_{1-2} \mathrm{P}_{3} \mathrm{H}_{4} \mathrm{P}_{5-6} \mathrm{H}_{7-8}(\mathrm{E} 24 \mathrm{D} \& \mathrm{E} 83 \mathrm{G})(\bullet)$. Enzyme activity at the optimum temperature (activity) or at the beginning of incubation (stability) was assumed to be $100 \%$. 
The optimum $\mathrm{pH}$ of $\mathrm{H}_{1-2} \mathrm{P}_{3} \mathrm{H}_{4} \mathrm{P}_{5-6} \mathrm{H}_{7-8}$ (E24D \& E83G) was determined over a $\mathrm{pH}$ range of 6.0-11.0. According to the $\mathrm{pH}$ activity profile shown in Figure 9a, maximum activity was observed for all three uricases at $\mathrm{pH}$ 8.5. Pre-incubation in buffer with $\mathrm{pH}$ ranging from 6.5 to 11.0 did not cause substantial loss of activity in all three uricases, with more than $80 \%$ activity retained. Pre-incubation at $\mathrm{pH} 6$ was deteriorating due to the enzymatic activity of $\mathrm{H}_{1-2} \mathrm{P}_{3} \mathrm{H}_{4} \mathrm{P}_{5-6} \mathrm{H}_{7-8}$ (E24D \& E83G), with nearly $50 \%$ loss of activity (Figure 9b).
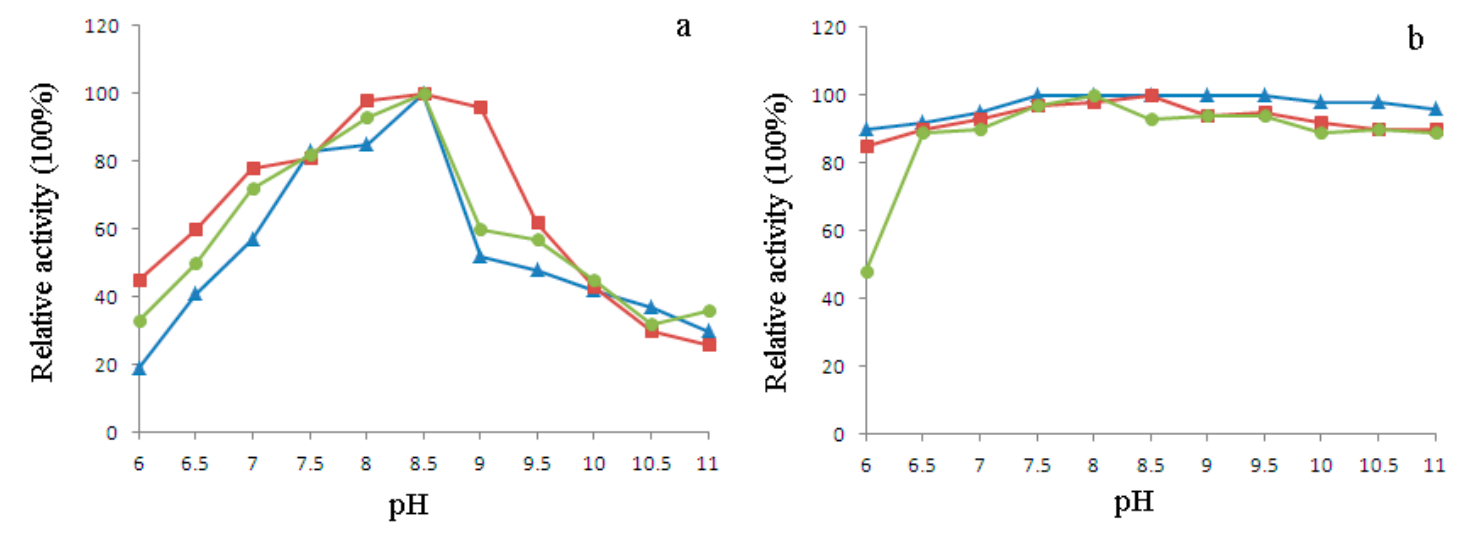

Figure 9. Effect of $\mathrm{pH}$ on uricolytic activity (a) and stability (b) of $\mathrm{wPU}(\boldsymbol{\Delta}), \operatorname{PBC}(\mathbf{\square})$, and $\mathrm{H}_{1-2} \mathrm{P}_{3} \mathrm{H}_{4} \mathrm{P}_{5-6} \mathrm{H}_{7-8}$ (E24D \& E83G) (•). Enzyme activity at the optimum pH (activity) or at the beginning of incubation (stability) was assumed to be $100 \%$.

\section{Discussion}

The buildup of serum urate in the blood (hyperuricemia) can have severe consequences for human health. Although Uox preparations are very promising therapies for hyperuricemia and gout, their clinical use has been restricted by immunogenicity, the same as other non-human proteins with useful therapeutic properties. In the development of therapeutic uricase for human use, there should be a balance between activity, stability, and immunoreactivity. Molecular engineering has been frequently applied to construct enzymes with desired properties [26-28]. Due to the lack of detailed structure-activity correlation of uricase, rational design is not feasible for engineering the enzyme. Previously, we obtained a more human-like chimeric uricase by DNA shuffling, which was an irrational method of molecular engineering [29]. $d h u$ and wpu were used as parental genes to generate a diverse chimeric library from which mutant chimeras with desired properties were selected. However, this molecular engineering strategy was relatively tedious and relied greatly on the availability of high-throughput screening methodology.

The activity of human uricase was gradually lost during hominoids' evolution as a result of the accumulation of both nonsense mutations and missense mutations [30]. It has been proved that human uricase cannot be resurrected simply by replacing the two premature stop codons 33 and 187 present in the pesudogene, leading to the speculation that elimination of other missense mutations are needed to restore the activity. Kratzer et al. used site-directed mutagenesis to determine the amino acid substitutions responsible for the decreases in human uricase activity [31]. From the ancestral uricase An19/22 to nonfunctional human uricase, there are 22 amino acids replacement (including codons 33 and 187); nearly all of them are deleterious to enzymatic activity. However, permutation and combination of the remaining 20 missense mutations will result in numerous scenarios, and the construction of these mutants and screening for active ones will become an insuperable task. In this study, we demonstrated successful development of a chimeric uricase with increased homology with $\mathrm{dHU}$ and activity through a combination of exon replacement/restoration and site-directed mutagenesis, which could be considered a semi-rational approach.

Silencing or pseudogenization of the human uricase gene is a result of multiple, independent evolutionary events. Although not protein-coding, a pseudogene represents a record of once-functional 
genetic characteristics. Despite increased sequencing and annotation of pseudogenes, they tend to be ignored. In our study, the sequence of human uricase pseudogene was used for the development of a drug candidate that is more human-like than the FDA-approved PBC, setting a good example for exploring the full potential of pseudogenes. With a high homology with $\mathrm{dHU}, \mathrm{wPU}$ is also the most active among other mammalian uricases [32]. Both wPU and dHU are composed of 304 amino acids, which are distributed into exons with exactly the same length. Each exon in wpu can be considered as the functional counterpart of $d h u$. Therefore, we decided to construct porcine-human chimeric uricase by exon replacement, which allowed for investigation of these mutations collectively within an exon. In the subsequent exon restoration, the activity of $\mathrm{dHU}$ was recovered by replacing those significantly deleterious exons. This semi-rational approach circumvents the tedious screening of the irrational approach and allows for the study of exon-based structure-activity correlation.

An exon replacement study showed that exon 6 had the greatest detrimental effect, leading to a total loss of activity. This was consistent with a previous study by Kratzer et al. [31]. The three mutations during hominoids' evolution with the largest deleterious effect on the catalytic activity of uricase are all distributed in exon 6-S232L, Y240C, and F222S. A single mutation of S232L nearly abolished the catalytic activity of uricase An19/22, the ancestral uricase with much higher activity than wPU. The other two mutations prevented uricase solubility and thus the determination of activity [30]. It is very reasonable to conclude that mutations in exon 6 are the predominant reason for the inactivation of HU. From the most deteriorating to the least destructive, exons in $d h u$ follow this sequence: exon 6 , exon 5 , exon 3, exons $1-2$, exon 4 , and exons $7-8$. It is interesting to note that exon 5 in $d h u$ was only two amino acids (positions 202 and 208) different from that of wPU; however, a much larger detrimental effect on enzymatic activity was produced than the collective effect of all the eight mutations existing in exon 3. Exons with a significant detrimental effect on human uricase were chosen to be replaced by the corresponding exons in wpu to restore dHU activity. After replacement of three exons, moderate activity was detected for chimera $\mathrm{H}_{1-2} \mathrm{P}_{3} \mathrm{H}_{4} \mathrm{P}_{5-6} \mathrm{H}_{7-8}$. However, this activity was too low to have any clinical significance.

In order to further increase the activity of porcine-human uricase to an acceptable level and at the same time retain a high degree of homology to $\mathrm{dHU}$, exon restoration was not continued for exons 1-2, 4 , and 7-8. An exon replacement study suggested that mutations in these five exons were generally not so detrimental to the enzyme activity. However, some of them may be more liablethan others. Our strategy was to identify the more liablemutations in these five exons by multiple sequence alignment and homology modeling. Sequence alignment of functional uricase and non-functional uricase revealed that $24 \mathrm{E}$ and $83 \mathrm{E}$ were shared by nonfunctional $\mathrm{dHU}$ and $\mathrm{H}_{1-2} \mathrm{P}_{3} \mathrm{H}_{4} \mathrm{P}_{5-6} \mathrm{H}_{7-8}$ with poor activity, while $24 \mathrm{D}$ and $83 \mathrm{G}$ were found in all other uricases in the alignment with relatively high activity. We hypothesized that 24D and 83G might be critical for enzyme activity, which was further predicted by molecular modeling. In our analysis of the modeled $3 \mathrm{D}$ structures, $24 \mathrm{E}$ in $\mathrm{H}_{1-2} \mathrm{P}_{3} \mathrm{H}_{4} \mathrm{P}_{5-6} \mathrm{H}_{7-8}$ results in increased distance between the two dimers of uricase homotetramer and is thus disadvantageous to enzyme activity. With a larger side chain than glycine, glutamic acid at position 83 increases the steric hindrance at the cornering between the two $\alpha$-helixes of uricase monomer and thus adversely affects the accurate positioning of active residues of the enzyme. Based on these predictions, site-directed mutagenesis was performed to obtain chimera $\mathrm{H}_{1-2} \mathrm{P}_{3} \mathrm{H}_{4} \mathrm{P}_{5-6} \mathrm{H}_{7-8}$ (E24D \& E83G), which was more homologous to $\mathrm{dHU}$ and more active than $\mathrm{PBC}$.

\section{Materials and Methods}

\subsection{Microorganisms, Vectors, and Materials}

Host strain E. coli BL 21 Star $^{\mathrm{TM}}$ (DE3) and vector pET-22b(+) were from Invitrogen (Carlsbad, CA, USA). DNA polymerase, DNA marker, T4 DNA ligase, and restriction endonucleases Nde I and Hind III were from Fermentas (Waltham, MA, USA). A polymerase chain reaction (PCR) amplification kit (including PCR buffer and dNTP mix) was obtained from Takara (Shiga, Japan). The plasmid mini 
kit I and PCR product recovery kit were purchased from Omega Bio-Tek (Norcross, GA, USA). Uric acid standard was from Sigma-Aldrich (St. Louis, MO, USA). All other reagents were of analytical grade.

\subsection{Construction of $d H U, w P U$, and Porcine-Human Chimeras}

A codon-optimized full length dHU gene with two premature mutations at codon 33 and 187 replaced by CGA (arginine) was designed and synthesized based on the hypothetic protein sequence of HU. Restriction sites Nde I and Hind III were introduced at the $5^{\prime}$-and $3^{\prime}$-terminus respectively. After digestion and ligation, $d h u$ was inserted into the multiple cloning site of pET-22b(+) vector. The wPU gene was also chemically synthesized in a similar manner and constructed into a pET-22b(+) vector. A PBC gene was accidentally obtained in our previous study on DNA shuffling between wpu and $d h u$.

In the exon replacement study, each exon in wpu was replaced by the corresponding exon in $d h u$ to investigate the combined effect of all mutations accumulated during evolution in one exon on the activity of uricase. The plasmid and strains in this study are shown in Table 2. The procedures are briefly described by taking exon 3 as an example. The nucleotide sequence of exon 3 in $d h u$ was amplified using primers 15 and 16 in Table S1. In order to substitute the corresponding exon in wpu, two bulky fragments containing exons 1-2 and exons 4-8 were amplified from wpu using primers $1 \& 2$ and $5 \& 12$. With overlapping sequences, the two bulky fragments were spliced, with exon 3 amplified from $d h u$ by overlap extension PCR (SOE-PCR). Replacement of other exons was carried out in a similar manner. In the subsequent exon restoration study, the three most deleterious exons in $d h u$ were replaced by the corresponding exons in wpu one after another to gradually restore the activity of dHU. The primers used for splicing were designed according to the nucleotide sequence of each exon in $d h u$ and $w p u$ by Primer Premier 5.0 and are shown in Table S1. All the chimeric genes were confirmed by DNA sequencing. All the recombinant plasmids were transformed into E. coli BL 21. Positive clones were screened on an LB plate supplemented with $100 \mu \mathrm{g} / \mathrm{mL}$ ampicillin.

Table 2. List of plasmids and strains in this study.

\begin{tabular}{|c|c|c|}
\hline Strain/Plasmid & Description & Source/Reference \\
\hline \multicolumn{3}{|l|}{ Strain } \\
\hline E.coli BL 21 Star ${ }^{\mathrm{TM}}$ (DE3) & Cloning host & Invitrogen \\
\hline \multicolumn{3}{|l|}{ Plasmid } \\
\hline pET-22b(+) & T7 promoter, $A m p^{R}$ & EMD Biosciences \\
\hline pET-22b(+)_H H $_{1-2}$ & coding for $\mathrm{H}_{1-2} \mathrm{P}_{3-8}$ & This study \\
\hline pET-22b(+)_- $\mathrm{H}_{3}$ & coding for $\mathrm{P}_{1-2} \mathrm{H}_{3} \mathrm{P}_{4-8}$ & This study \\
\hline pET-22b(+)_H & coding for $\mathrm{P}_{1-3} \mathrm{H}_{4} \mathrm{P}_{5-8}$ & This study \\
\hline pET-22b(+)_H & coding for $\mathrm{P}_{1-4} \mathrm{H}_{5} \mathrm{P}_{6-8}$ & This study \\
\hline pET-22b $(+)_{-} \mathrm{H}_{6}$ & coding for $\mathrm{P}_{1-5} \mathrm{H}_{6} \mathrm{P}_{7-8}$ & This study \\
\hline pET-22b(+)_H & coding for $\mathrm{P}_{1-6} \mathrm{H}_{7-8}$ & This study \\
\hline pET-22b(+)_P & coding for $\mathrm{H}_{1-5} \mathrm{P}_{6} \mathrm{H}_{7-8}$ & This study \\
\hline $\mathrm{pET}-22 \mathrm{~b}(+) \mathrm{P}_{5-6}$ & coding for $\mathrm{H}_{1-4} \mathrm{P}_{5-6} \mathrm{H}_{7-8}$ & This study \\
\hline pET-22b(+)_P $P_{3-5-6}$ & coding for $\mathrm{H}_{1-2} \mathrm{P}_{3} \mathrm{H}_{4} \mathrm{P}_{5-6} \mathrm{H}_{7-8}$ & This study \\
\hline pET-22b(+)_24 & coding for $\mathrm{H}_{1-2} \mathrm{P}_{3} \mathrm{H}_{4} \mathrm{P}_{5-6} \mathrm{H}_{7-8}(\mathrm{E} 24 \mathrm{D})$ & This study \\
\hline pET-22b(+)_24-83 & coding for $\mathrm{H}_{1-2} \mathrm{P}_{3} \mathrm{H}_{4} \mathrm{P}_{5-6} \mathrm{H}_{7-8}(\mathrm{E} 24 \mathrm{D} \& \mathrm{E} 83 \mathrm{G})$ & This study \\
\hline
\end{tabular}

\subsection{Expression and Purification of Porcine-Human Chimeras (PHC), wPU, and PBC}

For expression of each chimeric enzyme, a seed culture was prepared by overnight cultivation in an LB medium containing $100 \mu \mathrm{g} / \mathrm{mL}$ ampicillin and then inoculated into a fresh fermentation medium. After cultivation at $37^{\circ} \mathrm{C}$ for $4 \mathrm{~h}$, protein expression was induced by the addition of isopropyl- $\beta$-D-thiogalactoside (IPTG; $0.2 \mathrm{mM}$ final concentration), followed by further cultivation for $6 \mathrm{~h}$. Cells were harvested by centrifugation at $10,000 \times g$ for $10 \mathrm{~min}$ at $4{ }^{\circ} \mathrm{C}$. The cells' pellets 
were re-suspended in a lysis buffer and homogenized by sonication. The cell lysate was centrifuged at $10,000 \times g$ for $20 \mathrm{~min}$ at $4{ }^{\circ} \mathrm{C}$ to completely remove the cell debris. Solid ammonium sulfate was added to the recovered supernatant to $10 \%$ saturation at $4{ }^{\circ} \mathrm{C}$. The precipitate was re-dissolved in an $\mathrm{Na}_{2} \mathrm{CO}_{3}-\mathrm{NaHCO}_{3}$ buffer (0.1 M, pH 10.3), loaded onto an anion exchanger (Q-Sepharose Fast Flow), and eluted using $0.5 \mathrm{M} \mathrm{NaCl}$. Fractions showing uricolytic activities were pooled and loaded onto a Sephacryl S-300 column (GE Healthcare, Chicago, IL, USA). After elution with an $\mathrm{Na}_{2} \mathrm{CO}_{3}-\mathrm{NaHCO}_{3}$ buffer $(0.1 \mathrm{M}, \mathrm{pH} 10.3)$, target fractions were collected and stored at $4{ }^{\circ} \mathrm{C}$ for further analysis.

\subsection{Protein Analysis and Enzymatic Assay}

SDS-PAGE was carried out to determine the homogeneity of purification and the molecular mass of the chimeras [33]. Protein content was measured by the Bradford method with bovine serum albumin as a standard [34]. The enzymatic activity of purified uricase was determined spectrophotometrically by monitoring the decrease of uric acid in absorbance at $293 \mathrm{~nm}$ as described previously [35]. Solutions of uric acid were prepared in $50 \mathrm{mM}$ sodium borate buffer $\mathrm{pH} 8.5$ to a final concentration of $100 \mu \mathrm{M}$. Purified uricase was dissolved in the same buffer and mixed with the substrate. The enzymatic reaction was carried out at $37^{\circ} \mathrm{C}$ for 3 min with monitoring of absorbance at $293 \mathrm{~nm}$ every $4 \mathrm{~s}$. The maximum rate of decrease in the absorbance per minute was calculated. An extinction coefficient of $12,300 \mathrm{M}^{-1} \cdot \mathrm{cm}^{-1}$ for uric acid was used [36]. One unit (U) of enzymatic activity was defined as the amount of enzyme that consumes $1 \mu \mathrm{mol}$ of uric acid per minute. Specific activity was expressed as $\mathrm{U} / \mathrm{mg}$. The kinetic parameters $K_{m}$ and $V_{\max }$ of dHU, wPU, $\mathrm{H}_{1-2} \mathrm{P}_{3} \mathrm{H}_{4} \mathrm{P}_{5-6} \mathrm{H}_{7-8}$ (E24D \& E83G), and $\mathrm{PBC}$ were estimated by the double reciprocal plot method. Using different concentrations of uric acid $(0.001-0.144 \mathrm{mM})$, the enzyme activity was assayed as described above. The turnover number $\left(k_{c a t}\right)$ was calculated based on the value of $V_{\max }$, the concentration of the purified enzyme, and the molecular weight. $K_{m}$ was calculated by the Lineweaver-Burk plotting.

\subsection{Multiple Protein Sequence Alignment and Homology Modeling}

Amino acid sequences of three functional mammal uricases (pig, baboon, and dog) and three functional chimeric uricases (canine-human, porcine-human, and pig-baboon) were retrieved from GenBank or obtained from related patents. Multiple protein sequence alignment of those functional Uox with $\mathrm{H}_{1-2} \mathrm{P}_{3} \mathrm{H}_{4} \mathrm{P}_{5-6} \mathrm{H}_{7-8}$ and $\mathrm{dHU}$ was generated using Clustal $\mathrm{X}$ version 2.0 (Conway Institute, $\mathrm{UCD}$, Dublin, Ireland) to analyze the inconsistent residues across these sequences.

In order to predict the influence of specific amino acid residues (E24 and E83) on the activity of uricase, the 3D structure of mammalian uricase deposited by Ortlund and colleagues in the PDB database (PDI ID: 4MB8) was used as a template to model the 3D structures of mutated chimeric uricases using MOE 2010.10 (Chemical Computing Group Inc., Montreal, QC, Canada) [30].

\subsection{Site-Directed Mutagenesis of E24D and E83G}

Site-directed mutagenesis was implemented to obtain E24D and E24D \& E83G mutants of $\mathrm{H}_{1-2} \mathrm{P}_{3} \mathrm{H}_{4} \mathrm{P}_{5-6} \mathrm{H}_{7-8}$. Two pairs of primers (P13 \& 26 and $\mathrm{P} 24$ \& 25) with introduction of mutation E24D were designed against the gene fragments coding for amino acid residues 1-36 and 22-304 of $\mathrm{H}_{1-2} \mathrm{P}_{3} \mathrm{H}_{4} \mathrm{P}_{5-6} \mathrm{H}_{7-8}$ (see Table S1) using Primer Premier 5. The two gene fragments were amplified and spliced by SOE-PCR, resulting in mutant $\mathrm{H}_{1-2} \mathrm{P}_{3} \mathrm{H}_{4} \mathrm{P}_{5-6} \mathrm{H}_{7-8}$ (E24D). Mutation E83G was further introduced into the E24D mutant by similar procedures, using primer pairs P27 \& 24 and P13 \& 28 . After transformation into E. coli BL 21, positive clones harboring the recombinant plasmid were obtained and mutations were confirmed by DNA sequencing. Chimeric enzymes were expressed and purified according to the same procedures described above.

\subsection{Simulation of Interaction between Uricase $\mathrm{H}_{1-2} \mathrm{P}_{3} \mathrm{H}_{4} \mathrm{P}_{5-6} \mathrm{H}_{7-8}$ (E24D \& E83G) and Uric Acid}

In order to predict the interaction between uricase $\mathrm{H}_{1-2} \mathrm{P}_{3} \mathrm{H}_{4} \mathrm{P}_{5-6} \mathrm{H}_{7-8}$ (E24D \& E83G) and uric acid, structural modeling of uric acid to the binding site of uricase $\mathrm{H}_{1-2} \mathrm{P}_{3} \mathrm{H}_{4} \mathrm{P}_{5-6} \mathrm{H}_{7-8}$ (E24D \& E83G) 
was performed in silico by employing MOE 2010.10. 4MB8 was superposed to Arthrobacter globiformis uricase (PDI ID: 2YZB), whose crystal structure was complexed with uric acid. With three conserved residues in the active site (Q236, R187, and F170), a conserved water molecule involved in catalytic activity and the two residues (N262 and T68) hydrogen-bonded to it restrained, the 4MB8 structure complexed with uric acid was modeled and further used as a template to model the 3D structures of uricase $\mathrm{H}_{1-2} \mathrm{P}_{3} \mathrm{H}_{4} \mathrm{P}_{5-6} \mathrm{H}_{7-8}$ (E24D \& E83G). Interaction between uric acid and the binding site of uricase $\mathrm{H}_{1-2} \mathrm{P}_{3} \mathrm{H}_{4} \mathrm{P}_{5-6} \mathrm{H}_{7-8}$ (E24D \& E83G) was simulated in 2D view and 3D view by employing MOE 2010.10 and Visualizer module of Discovery studio (DS) 3.0 package (Accelrys Software, Inc., San Diego, CA, USA), respectively.

\subsection{Effect of $\mathrm{pH}$ and Temperature on the Activity of $\mathrm{H}_{1-2} \mathrm{P}_{3} \mathrm{H}_{4} \mathrm{P}_{5-6} \mathrm{H}_{7-8}$ (E24D \& E83G)}

The effect of $\mathrm{pH}$ and temperature on the enzyme activity of $\mathrm{H}_{1-2} \mathrm{P}_{3} \mathrm{H}_{4} \mathrm{P}_{5-6} \mathrm{H}_{7-8}$ (E24D \& E83G) was investigated by determining its uricolytic activity at a $\mathrm{pH}$ range of $6.0-11.0$ using different buffer systems $\left(\mathrm{NaH}_{2} \mathrm{PO}_{3}-\mathrm{Na}_{2} \mathrm{HPO}_{3}\right.$ 6.0-7.0, borate buffer $\mathrm{pH}$ 7.0-9.0, $\mathrm{Na}_{2} \mathrm{CO}_{3}-\mathrm{NaHCO}_{3}$ buffer $\mathrm{pH}$ 9.0-11.0) as well as a temperature range of $20-70{ }^{\circ} \mathrm{C}$. The results were expressed as the percentage of activity obtained at either the optimum $\mathrm{pH}$ or the optimum temperature. WPU and $\mathrm{PBC}$ were also included for comparison. pH stability of $\mathrm{H}_{1-2} \mathrm{P}_{3} \mathrm{H}_{4} \mathrm{P}_{5-6} \mathrm{H}_{7-8}$ (E24D \& E83G) was measured by pre-incubating (in a ratio of 1:1) the enzyme solution in the abovementioned buffer systems for $30 \mathrm{~min}$ at room temperature and subsequently measuring its activity at $35^{\circ} \mathrm{C}$. The percentage of residual enzyme activity was calculated by assuming enzyme activity at the beginning of the reaction as $100 \%$. Thermal stability of the enzyme was determined by pre-incubating the enzyme at different temperatures for $30 \mathrm{~min}$. The percentage of residual enzyme activity was determined after cooling or warming the sample to $35^{\circ} \mathrm{C}$.

\section{Conclusions}

In conclusion, we applied a semi-rational approach to develop a chimeric uricase for hyperuricemia and gout. Exon replacement and exon restoration were designed to identify the more detrimental exons and restore enzyme activity. Sequence alignment and homology modeling were successfully applied to predict favorable mutations. With increased homology with dHU, higher activity than $\mathrm{PBC}$, and good $\mathrm{pH}$ and thermal stability, the resulting chimera $\mathrm{H}_{1-2} \mathrm{P}_{3} \mathrm{H}_{4} \mathrm{P}_{5-6} \mathrm{H}_{7-8}$ (E24D \& E83G) is a more promising drug candidate for hyperuricemia and gout.

Supplementary Materials: Supplementary materials can be found at http:/ /www.mdpi.com/1422-0067/17/ 5/764/s1.

Acknowledgments: This study was supported the by Natural Science Foundation of Jiangsu Province of China (No.SKB2014021911), the National Natural Science Foundation of China (No. 308731192 and 81072560), and "111 Project" from the Ministry of Education of China and State Administration of Foreign Experts Affairs of China (No. 111-2-07). This study was also supported by a project funded by the Priority Academic Program Development of Jiangsu Higher Education Institutions.

Author Contributions: Jianhua Chen and Min Wang conceived and designed the project; Guangrong Xie and Weizhen Yang performed the experiments; Guangrong Xie, Weizhen Yang, Jing Chen, Miaomiao Li, Nan Jiang, Baixue Zhao, Si Chen analyzed the data; Weizhen Yang, Jing Chen, and Jianhua Chen wrote the paper. All authors read and approved the final manuscript.

Conflicts of Interest: The authors declare no conflict of interest.

\section{References}

1. Kahn, K.; Serfozo, P.; Tipton, P.A. Identification of the true product of the urate oxidase reaction. J. Am. Chem. Soc. 1997, 119, 5435-5442. [CrossRef]

2. Hayashi, S.; Fujiwara, S.; Noguchi, T. Evolution of urate-degrading enzymes in animal peroxisomes. Cell. Biochem. Biophys. 2000, 32, 123-129. [CrossRef]

3. Ramazzina, I.; Folli, C.; Secchi, A.; Berni, R.; Percudani, R. Completing the uric acid degradation pathway through phylogenetic comparison of whole genomes. Nat. Chem. Biol. 2006, 2, 144-148. [CrossRef] [PubMed] 
4. Roch-Ramel, F.; Peters, G. Urinary excretion of uric acid in nonhuman mammalian species. Handb. Exp. Pharmacol. 1978, 51, 211-255.

5. Wu, X.W.; Muzny, D.M.; Lee, C.C.; Caskey, C.T. Two independent mutational events in the loss of urate oxidase during hominoid evolution. J. Mol. Evol. 1992, 34, 78-84. [CrossRef] [PubMed]

6. Johnson, R.J.; Segal, M.S.; Srinivas, T.; Ejaz, A.; Mu, W.; Roncal, C.; Sánchez-Lozada, L.G.; Gersch, M.; Rodriguez-Iturbe, B.; Kang, D.H.; et al. Essential hypertension, progressive renal disease, and uric acid: A pathogenetic link? J. Am. Soc. Nephrol. 2005, 16, 1909-1919. [CrossRef] [PubMed]

7. Del, G.T.; Morris, E.; Cairo, M.S. Tumor lysis syndrome: Pathophysiology, definition, and alternative treatment approaches. Clin. Adv. Hematol. Oncol. 2005, 3, 54-61.

8. Liebman, S.E.; Taylor, J.G.; Bushinsky, D.A. Uric acid nephrolithiasis. Curr. Rheumatol. Rep. 2007, 9, $251-257$. [CrossRef] [PubMed]

9. Alderman, M.H.; Cohen, H.; Madhavan, S.; Kivlighn, S. Serum uric acid and cardiovascular events in successfully treated hypertensive patients. Hypertension 1999, 34, 144-150. [PubMed]

10. Verdecchia, P.; Schillaci, G.; Reboldi, G.; Santeusanio, F.; Porcellati, C.; Brunetti, P. Relation between serum uric acid and risk of cardiovascular disease in essential hypertension. The PIUMA study. Hypertension 2000, 36, 1072-1078. [CrossRef] [PubMed]

11. Sarawate, C.A.; Brewer, K.K.; Wenya, Y.; Patel, P.A.; Schumacher, H.R.; Saag, K.G.; Bakst, A.W. Gout medication treatment patterns and adherence to standards of care from a managed care perspective. Mayo Clin. Proc. 2006, 81, 925-934. [CrossRef] [PubMed]

12. Annemans, L.; Spaepen, E.; Gaskin, M.; Bonnemaire, M.; Malier, V.; Gilbert, T.; Nuki, G. Gout in the UK and Germany: Prevalence, comorbidities and management in general practice 2000-2005. Ann. Rheum. Dis. 2008, 67, 960-966. [CrossRef] [PubMed]

13. Singer, J.Z.; Wallace, S.L. The allopurinol hypersensitivity syndrome. Unnecessary morbidity and mortality. Arthritis Rheum. 1986, 29, 82-87. [CrossRef] [PubMed]

14. Arellano, F.; Sacristán, J.A. Alloputinol hypersensitivity syndrome: A review. Ann. Pharmacother. 1993, 27, 337-343. [PubMed]

15. Goldman, S.C.; Holcenberg, J.S.; Finkelestein, J.Z.; Hutchinson, B.; Kreissman, S.; Johnson, F.L.; Tou, C.; Harvey, E.; Morris, E.; Cairo, M.S. A randomized comparison between rasburicase and allopurinol in children with lymphoma or leukemia at high risk for tumor lysis. Blood 2001, 97, 2998-3003. [CrossRef] [PubMed]

16. Jeha, S.C. Recombinant urate oxidase (rasburicase) in the prophylaxis and treatment of tumor lysis syndrome. Contrib. Nephrol. 2005, 147, 69-79. [PubMed]

17. Cammalleri, L.; Malaguarnera, M. Rasburicase represents a new tool for hyperuricemia in tumor lysis syndrome and in gout. Int. J. Med. Sci. 2007, 4, 83-93. [CrossRef] [PubMed]

18. Bertrand, Y.; Mechinaud, F.; Brethon, B.; Mialou, V.; Auvrignon, A.; Nelken, B.; Notz-Carrère, A.; Plantaz, D.; Patte, C.; Urbieta, M.; et al. SFCE recommendations for the management of tumor lysis syndrome (TLS) with rasburicase: An observational survey. J. Pediatr. Hematol. Oncol. 2008, 30, 267-271. [CrossRef] [PubMed]

19. Burns, C.M.; Wortmann, R.L. Gout therapeutics: New drugs for an old disease. Lancet 2010, 377, $165-177$. [CrossRef]

20. Sundy, J.S.; Becker, M.A.; Baraf, H.S.; Barkhuizen, A.; Moreland, L.W.; Huang, W.; Waltrip, R.W.; Maroli, A.N.; Horowitz, Z.; Pegloticase Phase 2 Study Investigators. Reduction of plasma urate levels following treatment with multiple doses of pegloticase (polyethylene glycol-conjugated uricase) in patients with treatment-failure gout: Results of a phase II randomized study. Arthritis Rheum. 2008, 58, 2882-2891. [CrossRef] [PubMed]

21. Schlesinger, N.; Yasothan, U.; Kirkpatrick, P. Pegloticase. Nat. Rev. Drug. Discov. 2011, 10, 17-18. [CrossRef] [PubMed]

22. Fan, K.; Zhang, C.; Ma, X.; Mei, X.; Hu, C. Humanized Recombinant Uricase and Mutants Thereof. U.S. Patent US8586535 B2, 19 November 2013.

23. Rong, J.; Kuang, H.; Sun, Z. Preparation and Application of PEG Recombinant Pig-Human Urate Oxidase Fusion Protein. CN Patent CN102260653 B, 3 April 2013.

24. Yang, X.; Yuan, Y.; Zhan, C.G.; Liao, F. Uricase as therapeutic agent to treat refractory gout: Current states and future directions. Drug Dev. Res. 2012, 73, 66-72. [CrossRef] [PubMed]

25. Yeldandi, A.V.; Patel, Y.D.; Liao, M.; Kao, F.T.; Rao, M.S.; Reddy, J.K.; Le Beau, M.M. Localization of the human urate oxidase gene (UOX) to 1p22. Cytogenet. Cell Genet. 1992, 61, 121-122. [CrossRef] [PubMed] 
26. Wang, T.; Yuan, C.; Hwang, H.T.; Zhao, X.; Ramkrishna, D.; Liu, D.; Varma, A. Engineering surface hydrophobicity improves activity of Bacillus thermocatenulatuslipase 2 enzyme. Biotechnol. J. 2015, 10, 1762-1769.

27. Stephens, D.E.; Khan, F.I.; Singh, P.; Bisetty, K.; Singh, S.; Permaul, K. Creation of thermostable and alkaline stable xylanase variants by DNA shuffling. J. Biotechnol. 2014, 187, 139-146. [CrossRef] [PubMed]

28. Singh, S.K.; Heng, C.; Braker, J.D.; Chan, V.J.; Lee, C.C.; Jordan, D.B.; Yuan, L.; Wagschal, K. Directed evolution of GH43 $\beta$-xylosidase XylBH43 thermal stability and L186 saturation mutagenesis. J. Ind. Microbiol. Biotechnol. 2014, 41, 489-498. [CrossRef] [PubMed]

29. Chen, J.; Jiang, N.; Wang, T.; Xie, G.; Zhang, Z.; Li, H.; Yuan, J.; Sun, Z.; Chen, J. DNA shuffling of uricase gene leads to a more "human like" chimeric uricase with increased uricolytic activity. Int. J. Biol. Macromol. 2016, 82, 522-529. [CrossRef] [PubMed]

30. Oda, M.; Satta, Y.; Takenaka, O.; Takahata, N. Loss of urate oxidase activity in hominoids and its evolutionary implications. Mol. Biol. Evol. 2002, 19, 640-653. [CrossRef] [PubMed]

31. Kratzer, J.T.; Lanaspa, M.A.; Murphy, M.N.; Cicerchi, C.; Graves, C.L.; Tipton, P.A.; Ortlund, E.A.; Johnson, R.J.; Gaucher, E.A. Evolutionary history and metabolic insights of ancient mammalian uricases. Proc. Natl. Acad. Sci. USA 2014, 111, 3763-3768. [CrossRef] [PubMed]

32. Chang, B.S. Ancient insights into uric acid metabolism in primates. Proc. Natl. Acad. Sci. USA 2014, 1111, 3657-3658. [CrossRef] [PubMed]

33. Simpson, R.J. Purifying Proteins for Proteomics: A Laboratory Manual; Cold Spring Harbor Laboratory Press: New York, NY, USA, 2004.

34. Bradford, M.M. A rapid and sensitive method for the quantitation of microgram quantities of protein utilizing the principle of protein-dye binding. Anal. Biochem. 1976, 72, 248-254. [CrossRef]

35. Conley, T.G.; Priest, D.G. Thermodynamics and stoicheiometry of the binding of substrate analogues to uricase. Biochem. J. 1980, 187, 727-732. [CrossRef] [PubMed]

36. Kalckar, H.M. Differential spectrophotometry of purine compounds by means of specific enzymes; determination of hydroxypurine compounds. J. Biol. Chem. 1947, 167, 429-443. [PubMed]

(C) 2016 by the authors; licensee MDPI, Basel, Switzerland. This article is an open access article distributed under the terms and conditions of the Creative Commons Attribution (CC-BY) license (http://creativecommons.org/licenses/by/4.0/). 